Albelda Raga, José.

Sgaramella, Chiara.

Universitat Politècnica de València, Centro de Investigación Arte y Entorno.

\title{
Ecología global, sensibilidades locales. El rol de las humanidades ambientales frente a la crisis ecosocial contemporánea.
}

\section{Global ecology, local sensitivities. The role of environmental humanities in the face of the current ecosocial crisis.}

\author{
TIPO DE TRABAJO: \\ Comunicación. \\ PALABRAS CLAVE: \\ Arte, ecología, humanidades ambientales, transición, site specific. \\ KEY WORDS: \\ Art, ecology, environmental humanities, transition, site specific.
}

RESUMEN.

El proyecto de investigación interdisciplinar I+D+i titulado Humanidades ambientales. Estrategias para la empatía ecológica y la transición hacia sociedades sostenibles indaga el papel de la ética, de las artes visuales y de la literatura en el proceso de transformación necesario para establecer modelos culturales más eco-compatibles. En efecto, la crisis ecológica y social que vivimos plantea unos interrogantes profundos que nos obligan a repensarnos como seres humanos y como sociedad. Si bien existen significativos avances tecnocientíficos en el ámbito de la eficiencia energética o de la restauración ecosistémica, consideramos que para contrarrestar las poderosas inercias desarrollistas que caracterizan el paradigma actual es preciso potenciar un cambio de cosmovisión general de las sociedades, incluyendo su imaginario colectivo. En este sentido, las humanidades pueden cumplir un papel relevante en forjar nuevos valores e imaginar otras formas de convivencia social.

La presente comunicación recoge algunas de las propuestas presentadas en el primer seminario de investigación vinculado al ya mencionado proyecto I+D+i que tuvo lugar en la Universitat Politècnica de València en noviembre de 2016. En concreto, se exploran diferentes métodos de investigación desde las humanidades para abordar la dimensión global y local de la transición a la sostenibilidad. En primer lugar, se plantea un enfoque interdisciplinar para el estudio de fenómenos de escala planetaria, como la crisis energética y climática; junto a ello, se proponen talleres creativos vinculados a iniciativas ecológicas ciudadanas para conectar la investigación académica a los conocimientos locales. Finalmente, se evalúa la influencia y el potencial transformador de proyectos de creación artística y vinculados a una noción ampliada de site specific y a procesos de creación colaborativos en diálogo con las comunidades humanas e incluso con los elementos bióticos y abióticos del ecosistema. 


\section{ABSTRACT.}

The interdisciplinary research project entitled Environmental humanities. Strategies for ecological empathy and the transition towards sustainable societies investigates the role of ethics, visual arts and literature in the transformation process needed to implement more eco-compatible cultural models. The ecological and social crisis we face forces us to rethink ourselves as human beings and as a society. Despite the significant techno-scientific advances in the field of energy efficiency and ecosystem restoration, a change in our world view and collective imagination is necessary in order to balance the powerful cultural inertia that characterizes the current paradigm. In this sense, humanities can play a relevant role in forging new values and imagining other forms of social coexistence.

This paper analyzes some of the activities presented at the first international seminar carried out at the Polytechnic University of Valencia in November 2016 within the aforementioned research project. Different research methods in the field of humanities are taken into consideration to address the global and local dimension of the transition to sustainability. Firstly, an interdisciplinary approach is proposed for the study of global phenomena such as the energy and climate crisis. Moreover, creative workshops connected to citizen ecological initiatives are implemented to link academic research to local knowledge. Finally, we evaluate the influence and transformative potential of art projects exploring an expanded notion of site specific and adopting collaborative creation processes in dialogue with human communities, biotic and abiotic elements of the ecosystem. 